\title{
BIBECHANA
}

A Multidisciplinary Journal of Science, Technology and Mathematics ISSN 2091-0762 (Print), 2382-5340 (0nline)

Journal homepage: http://nepjol.info/index.php/BIBECHANA

Publisher: Research Council of Science and Technology, Biratnagar, Nepal

\section{Effect of position of irregularity in concrete frame on response to seismic forces}

\author{
Md. Tariqul Islam ${ }^{1}$,Md. Samdani Azad ${ }^{2 *}$, Md. Fahim Atif ${ }^{3}$, Gazi Md. Sharfaraz Imam Azad ${ }^{1}$ \\ ${ }^{1}$ Department of Civil Engineering, Rajshahi University of Engineering \& Technology (RUET). \\ ${ }^{2}$ Department of Civil and Environmental Engineering, Faculty of Engineering, Mahidol University, \\ Thailand. \\ ${ }^{3}$ Dhaka Mass Rapid Transit Development-Metro Rail Project. \\ "Email: samdani.civil.ruet@ gmail.com
}

Article history: Received 08 December, 2017; Accepted 17 December, 2017

DOI: http://dx.doi.org/10.3126/bibechana.v15i0.18718

This work is licensed under the Creative Commons CC BY-NC License.

https://creativecommons.org/licenses/by-nc/4.0/

This paper deals with the irregular profile of concrete frame building along vertical direction comprising of mass discontinuity and overhanging mass. The underlying fact of the paper is the effect of seismic force in concrete frames with different types of irregularities including mass discontinuity and overhanging mass. For each successive model, the position of overhanging mass and mass discontinuity is kept variable to make the study effective. This study delineates the vulnerable effect of mass discontinuity and overhanging mass in concrete frame buildings. To attain the nonlinear property of each element of frame, pushover analysis method along with the equivalent static force method has been adopted for the present study. UBC97 code has been used here for linear static analysis while the parameters for nonlinear static analysis are arrogated from FEMA356 and ATC40. Investigations on different frames exhibit that the location of mass discontinuity and overhanging mass can be a key matter to avoid risks due to earthquake. While considering the design of such frames which have irregularities, designer must think about the position of irregularity. Basically, vulnerability increases in case of mass discontinuity if the irregularity is in lower stories. Moreover, vulnerability increases in case of overhanging masses if the irregularity is in higher stories.

Keywords: Concrete frame; Pushover analysis; Mass discontinuity; Overhanging mass.

\section{Introduction}

Most notable events of major earthquakes took place in Bangladesh since 1762 to 2015 jolted large part of the country [1]. The frequent earthquakes have made the engineering community aware of the need of seismic evaluation and retrofitting of existing structures. Recent progress in the development of new architectural forms of buildings and high strength materials coupled with more pioneering computational methods and design procedures have led to a new generation of high-rise RC buildings drastically. Based on the technology advancement and knowledge gained after earthquake occurrences, the seismic code is usually revised by including new clauses and updating old provisions. Primary goal of seismic provisions in building codes is to protect life safety through the 
prevention of structural collapse. The failure of structure starts at points of weakness. This weakness arises due to discontinuity in mass, stiffness and geometry of structure. The structures having different discontinuities are termed as Irregular structures. Mass irregularity by reducing the mass in the upper part of the structure or by providing overhanging mass in concrete frame is commonly done in practice to meet client's requirements or architectural requirements. This type of irregularity, which is due to asymmetric distributions of mass, is one of the most frequent sources of severe damage, since it results in floor rotations (torsion response) in addition to floor translations. Different building codes provided seismic provisions for different irregularities. The paper presents an overview of the progress in research regarding seismic response of building structures with mass discontinuity or overhanging mass in different story levels.

Stefano \& Pintucchi [2] presented a review of the research on the seismic behavior of both plan and vertically irregular building structures. Tremblay and Poncet [3] examined the influence of mass irregularity for several eight-story structures with different mass discontinuity patterns. They made both the static analysis approach and dynamic analysis method for the presentation. Mass irregularity was found to have limited effects on the level of protection against structural collapse when static analysis was used. Dynamic analysis method did not seem to provide marked benefit on the response of the buildings with mass discontinuity. Nonlinear dynamic behavior of a set of five-story asymmetric buildings with different strength distribution was studied by Aziminejad and Moghadam [4] to investigate the effect of different strength distribution strategies. The results showed that for inter-story drift and plastic rotation parameters, models with lower diaphragm rotation perform better. But for the ductility demand parameter this situation is not valid. In torsionally stiff buildings, each of the models similar trends of responses was observed for Life Safety (LS) and Collapse Preventation (CP) limit states. In lower limit states such as IO, the effect of strength distribution on improvement of building performance decreases and in higher limit states such as $\mathrm{CP}$, the effect of strength distribution increases. An approximate seismic analysis was presented by Georgoussis et al. [5] for multi- story setback buildings with mass and stiffness irregularities subjected to strong ground motions. The method predicted the structural configuration of minimum torsion, which signified that the building elastic response during a ground motion is more or less translational. This response was preserved in the inelastic phase when the strength assignment of the lateral load resisting bents was derived from a planar static analysis, as a consequence of the almost concurrent yielding of these bents. Chintanapakdee \& Chopra [6] deliberated about the seismic response of vertically irregular frames. They investigated the effects of stiffness, strength, and combined stiffness and strength irregularity on seismic demands of strong column weak beam frames using response history analysis and modal pushover analysis. The three types of irregularities similarly influence the height wise variation of story drifts, with the effects of strength irregularity being larger than stiffness irregularity, and the effects of combined stiffness and strength irregularity being the largest among the three. Drift demands in the upper stories are much more sensitive to irregularities in the lower stories than the response of lower stories is affected by irregularities in the upper stories. Effects of the structural irregularity developed by the discontinuity of a column in a plane frame subjected to seismic loads including the gravity loads were investigated by Kara and Celep [7]. The results of the nonlinear static and dynamic analyses gave much more useful information regarding the irregularity than the linear analysis. The nonlinear story drift demand was found significantly large, when the column discontinuity was in the lower stories of the frame. Seismic response of building frames with vertical structural irregularities was discussed by Valmundsson and Nau [8]. In this paper, the mass, strength, and stiffness limits for regular buildings as specified by the Uniform Building Code (UBC) were evaluated. Conclusions were derived regarding the effects of the irregularities on shear forces and maximum ductility demands. It was found that the mass and stiffness criteria of UBC result in moderate increases in response quantities of irregular structures compared to regular structures. The strength criterion results in large increases in response quantities and was not consistent with the mass and stiffness requirements. Hosseini et al. [14] discussed on pushover analysis of RCC frames with bracings. They emphasized on the using of shear links in bracings and found positive affectivity of shear links. Six incompatible frames limited to six story were taken into consideration in this study to 
obtain the effect of mass irregularity. The aim of this research includes the effect of location of mass discontinuity and overhanging mass along vertical direction. There are some important points of this research which represents it bit different from the previous. Previous studies delineated on the analysis methods, stiffness, mass irregularities, comparison of drifts ratios. This research also deals with irregularity but the most noticeable point is their position. This paper deals with the position of mass discontinuity as well as overhanging mass. To investigate the nonlinear behavior along with the linear performance of selected frames, push over analysis is carried out. Pushover analysis has become the preferred method for performance based seismic performance evaluation of structures by the rehabilitation guidelines and codes because it is conceptually and computationally simple. Pushover analysis allows tracing the sequence of yielding and failure on member and structural level as well as the progress of overall capacity curve of the structure. The research output suggests maintaining overhanging mass in lower story and mass discontinuity in higher story according to the response of considered frames.

\section{Materials and Methods}

\subsection{Materials}

Specifications of materials used in the numerical analysis are detailed in Table 1. The loading conditions were adopted from UBC97 [9]. The interpretation was performed as per the guidelines of FEMA 356 [10]. The adopted properties of frame can be observed in Table 1 and in all frames; the beams and columns of same sizes were provided. All the properties in table are kept constant.

Table 1: Details of members used.

\begin{tabular}{|l|c|}
\hline Members & Configuration \\
\hline Beam size & $30 \mathrm{~cm} * 40 \mathrm{~cm}$ \\
\hline Column size & $30 \mathrm{~cm} * 30 \mathrm{~cm}$ \\
\hline Total story & 6 \\
\hline Bay width & $5 \mathrm{~m}$ \\
\hline Story height & $3 \mathrm{~m}$ \\
\hline
\end{tabular}

\subsection{Frame types}

Six concrete frames having vertical discontinuity in column and overhanging mass along height have been considered for the present study. All the considered 6 story frames are assumed to be fixed at ground level, floor to floor heights are taken as $3 \mathrm{~m}$ and bay width is taken as $5 \mathrm{~m}$ as described in Table 1.Constant beam and columns sizes were taken at all floors levels for each considered frame so that the numerical results can be interpreted easily, however number of columns and beams vary with respect to model. Fig. 1a (model-1) depicts the frame has vertically discontinuity after third floor. Fig. 1b (model-2) depicts a frame that has mass irregularity after second floor but has symmetry along the vertical axis. Fig. 1c (model-3) depicts a frame that has mass discontinuity at second floor. Fig. 1d (model-4), on the other hand, depicts an overhanging mass at $5^{\text {th }}$ story. Fig. 1e (model-5) depicts a frame that has an overhanging mass at $4^{\text {th }}$ story. Fig. $1 \mathrm{f}$ (model-6) depicts an overhanging mass at $3^{\text {rd }}$ story. It is noted that the locations of mass discontinuity and overhanging mass is variable.

\subsection{Methodology}

To understand the variations of nonlinear properties of different frames, pushover analysis has been conducted. Assessments of the certain frames can be done by conducting nonlinear static or pushover analysis. Pushover analysis method is mainly adopted in case of existing structures and to find out the nonlinear properties of frames. Assessment of effective stiffness, secant stiffness and ductility and target displacements along a certain direction can be determined by means of pushover analysis. The steel frames are assumed as ordinary moment resisting frames and ordinary braced frames. Pushover parameters have been taken from FEMA 356 Prestandard [10]. The behavior of structures can be comprehended from the force-displacement curve which is recognized as capacity curve. From Fig.2, the behavior of force displacement curve can be observed. As per the notations in the Fig. 2, point 
"A" represents the origin while point "B" represents the yield point. After point $D$, the element responds with substantially reduced strength to point $\mathrm{E}$. The boundaries required for pushover analysis have been conveyed from FEMA 356 [10]. The parameters from UBC97 [9] have been listed in Table 2 while the pushover criteria is shown in Table 3.

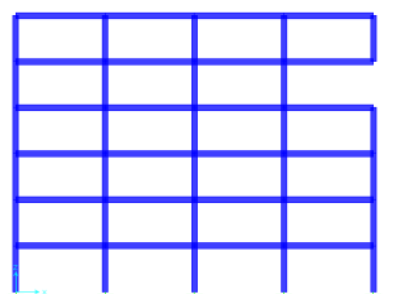

a. Model-1

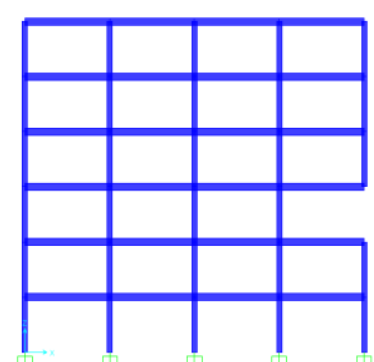

c. Model-3

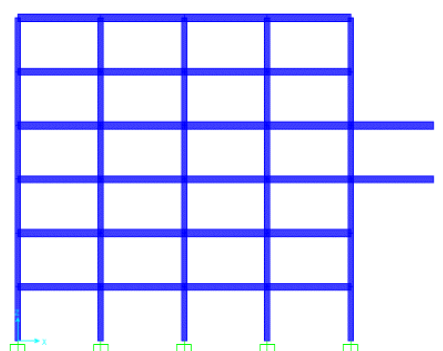

e. Model-5

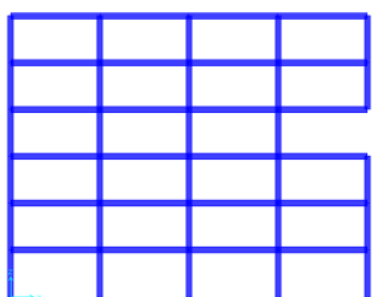

b. Model-2

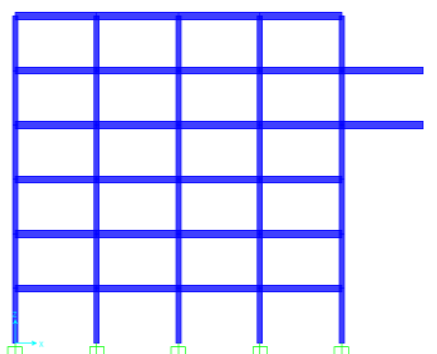

d. Model-4

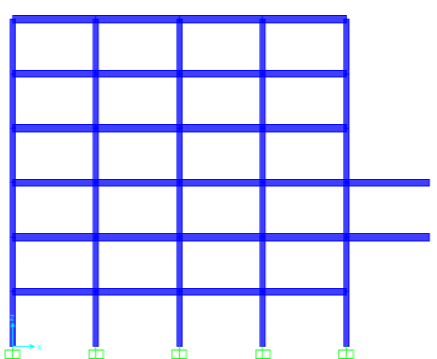

f. Model-6

Fig. 1: Selected Concrete Frames.

The Base shears which have been applied for pushover analysis was derived from the following equations.

$$
\begin{aligned}
& \mathrm{V}=\frac{\mathrm{C}_{\mathrm{v}} \mathrm{I}}{\mathrm{RT}} \mathrm{W} \\
& \text { where, } \mathrm{T}=\mathrm{C}_{\mathrm{t}}\left(\mathrm{h}_{\mathrm{n}}\right)^{3 / 4}
\end{aligned}
$$

The computed base shear (V) from equation (1) must be less than that calculated by equation (3) and must be greater than that calculated by equation (4). In equation (1), $W$ indicates the self-weight of the frame.

$$
\begin{aligned}
& \mathrm{V}=\frac{2.5 \mathrm{C}_{\mathrm{a}} \mathrm{I}}{\mathrm{R}} \mathrm{W} \\
& \mathrm{V}=0.11 \mathrm{C}_{\mathrm{a}} \mathrm{IW}
\end{aligned}
$$




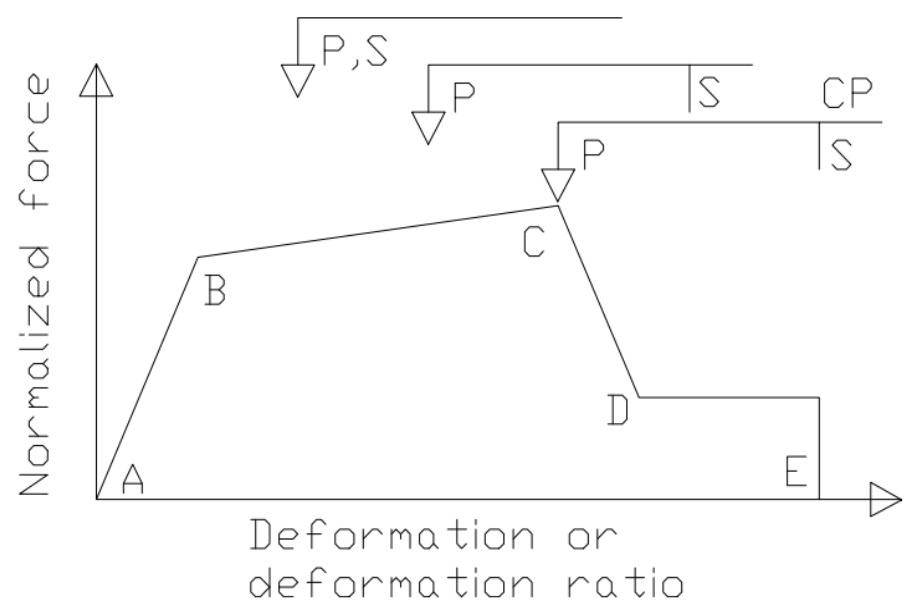

Fig. 2: Force vs. deformation/deformation ratio curve.

Reviewing the aspects adjudging pushover analysis, a number of facts are entailed to be adopted from FEMA356. The nonlinear behavior of certain structure can be assessed by dint of conjuring a nonlinear static analysis or pushover analysis. Staad.pro v8i has been utilized for pushover analysis. The assumptions through which the pushover analysis has been followed are listed below:

i) The frames are special moment resisting frames.

ii) The geometric nonlinearity with $\mathrm{P}-\Delta$ is considered.

iii) The nonlinear hinges are presumed as per FEMA356.

iv) Deduction of the damping ratio is $5 \%$ and the site class is $S_{c}$

v) Mapped spectral acceleration factor, $\mathrm{F}_{\mathrm{a}}=1.2$ and $\mathrm{F}_{\mathrm{v}}=1.7$

vi) $\quad \mathrm{C}_{\mathrm{a}}=0.09$ and $\mathrm{C}_{\mathrm{v}}=0.13$ was adopted as per ATC40 [11]

vii) A certain value of displacement has been entered to terminate the pushover analysis.

Both linear and nonlinear static analysis following equations (1-4) and maintaining the assumptions were also performed for each consecutive case to record the maximum deflection, story drift, capacity curve, ductility of frames, performance points.

Table-2 illustrates the seismic parameters considered in the study. Seismic Zone-I is considered for why the value of $Z$ is taken as 0.075 . The frames adopted for analysis are of special moment resisting type and the response modification factor is taken 8.5, seismic coefficients $C_{a}$ and $C_{v}$ are related to soil profile $S_{c}$ and values are taken according to UBC97. Moreover, the value of near source factors are also taken from UBC97.

Table-3 describes the pushover parameters that are applied for the analysis. The values of mapped spectral acceleration $F_{a}$ and $F_{v}$ are taken as per FEMA356. Site category class $C$ as per FEMA356 and it is similar to the soil profile type $S_{c}$ as per UBC97.

Table 2: Values considered from UBC97 [9].

\begin{tabular}{|l|c|}
\hline Parameters & Values/ Standards \\
\hline Zone factor, $\mathrm{Z}$ & 0.075 \\
\hline Soil profile type & $\mathrm{S}_{\mathrm{c}}$ \\
\hline Seismic importance factor, $\mathrm{I}$ & 1 \\
\hline Response modification factor, $\mathrm{R}$ & 8.5 \\
\hline Seismic coefficient, $\mathrm{C}_{\mathrm{a}}$ & 0.09 \\
\hline Seismic coefficient, $\mathrm{C}_{\mathrm{v}}$ & 0.13 \\
\hline Near-source factor, $\mathrm{N}_{\mathrm{a}}$ & 1 \\
\hline Near-source factor, $\mathrm{N}_{\mathrm{v}}$ & 1 \\
\hline $\mathrm{C}_{\mathrm{t}}$ & 0.073 \\
\hline
\end{tabular}


Table 3 Pushover parameters.

\begin{tabular}{|l|c|}
\hline \multicolumn{1}{|c|}{ Parameter } & Input value/system \\
\hline Frame type & Moment resisting frame \\
\hline Geometric Nonlinearity and $\mathrm{P}-\Delta$ effects & Included \\
\hline Hinge type & As per FEMA356 \\
\hline Damping & $5 \%$ \\
\hline Site category & Class $\mathrm{C}$ \\
\hline Mapped spectral acceleration, $\mathrm{F}_{\mathrm{a}}$ & 1.2 \\
\hline Mapped spectral acceleration, $\mathrm{F}_{\mathrm{v}}$ & 1.7 \\
\hline
\end{tabular}

\section{Analysis and Results}

The analysis of all the frames has been carried out following UBC97 [9] and FEMA356 [10] for linear static and nonlinear static/pushover analysis sequentially. The analyses depict inherent illustrations about the behavior of the frames of this research. The main intent of the research includes the computation of displacement under linear and nonlinear analysis with observing the nonlinear hinge formation in the members. The formation of nonlinear hinges at a certain load-step defines the load capacity of the certain member/element. Fig. 3 presents the different lateral displacements of different frames obtained from linear static analysis. It can be observed that Model-3 is susceptible to largest lateral displacements due to seismic forces.

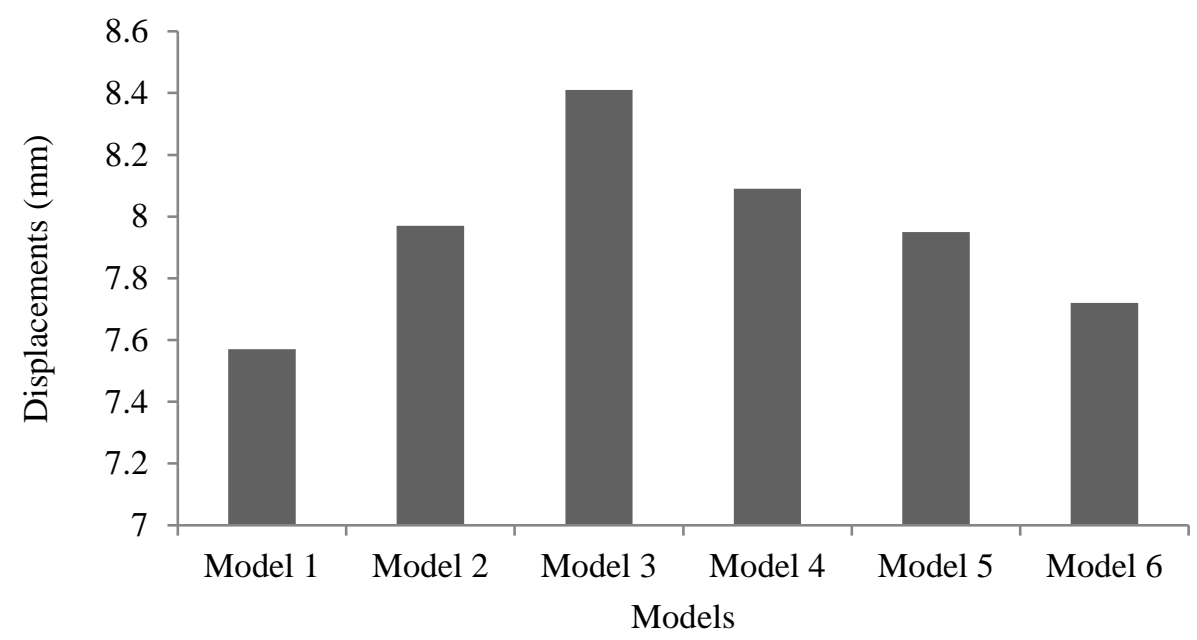

Fig. 3: Maximum roof displacements.

The reason behind this is that the discontinuous portion of the frame carries largest mass among Model [1-3]. On the contrary, this mass discontinuity decreases the total stiffness of the certain story level. This discontinuity decreased the stiffness of that portion of the frame. In Model-3, the mass discontinuity is in lower story level. That causes less stiffness in that story. This story carries higher loads of upper stories comparing the other two models. The second maximum displacement is observed in the Model-4. The overhanging mass is located in higher story. There is a reason behind it. If the overhanging mass is in higher story, it causes more overturning moment in the base. The effect of this extra overturning moment is added to the lateral forces and cause larger displacements. That is this graph represents a typical behavior of the frames which delineates that mass discontinuity in lower story and overhanging mass in higher story is liable to higher lateral displacements due to seismic forces. The value of lateral displacement of model-1 is around $7.58 \mathrm{~mm}$ which is the lowest among all the frames and highest value for model-3 is about $8.45 \mathrm{~mm}$. For the rest of the models this value ranges around $8 \mathrm{~mm}$. Fig. 4 deliberates the relation between story height and percentage of story drift ratio. It can be observed that the drift ratio at first, is increasing gradually in case of all the models and after a certain point it starts decreasing with height. But it doesn't continue upto the peak 
height rather it shows a different behavior in case of models-(1,2\&3). For model-1, it can be noted that the drift suddenly increases at $12 \mathrm{~m}$ to $15 \mathrm{~m}$ height. same issue can be observed for models ( 2 and 3 ). For model-2, the sudden increase occures at at $9 \mathrm{~m}$ to $12 \mathrm{~m}$ height and $6 \mathrm{~m}$ to $9 \mathrm{~m}$ height for model-3. Moreover, it is also subtantial that the mass discontinuity of models (1,2 and 3) starts at $12 \mathrm{~m}, 9 \mathrm{~m}$ and $6 \mathrm{~m}$ subssequently. The value of drift ratio abruptly changes in that story containing the mass discontinuety. Furthermore, Fig. 4 delineates one more thing. The peak story drift occurs at $6 \mathrm{~m}$ for model $(4,5$, and 6$)$. But it is already explained that the peak drift occurs at different height for models $(1,2$, and 3$)$ which illustrates that the story drift has the dependency of mass discontinuity.

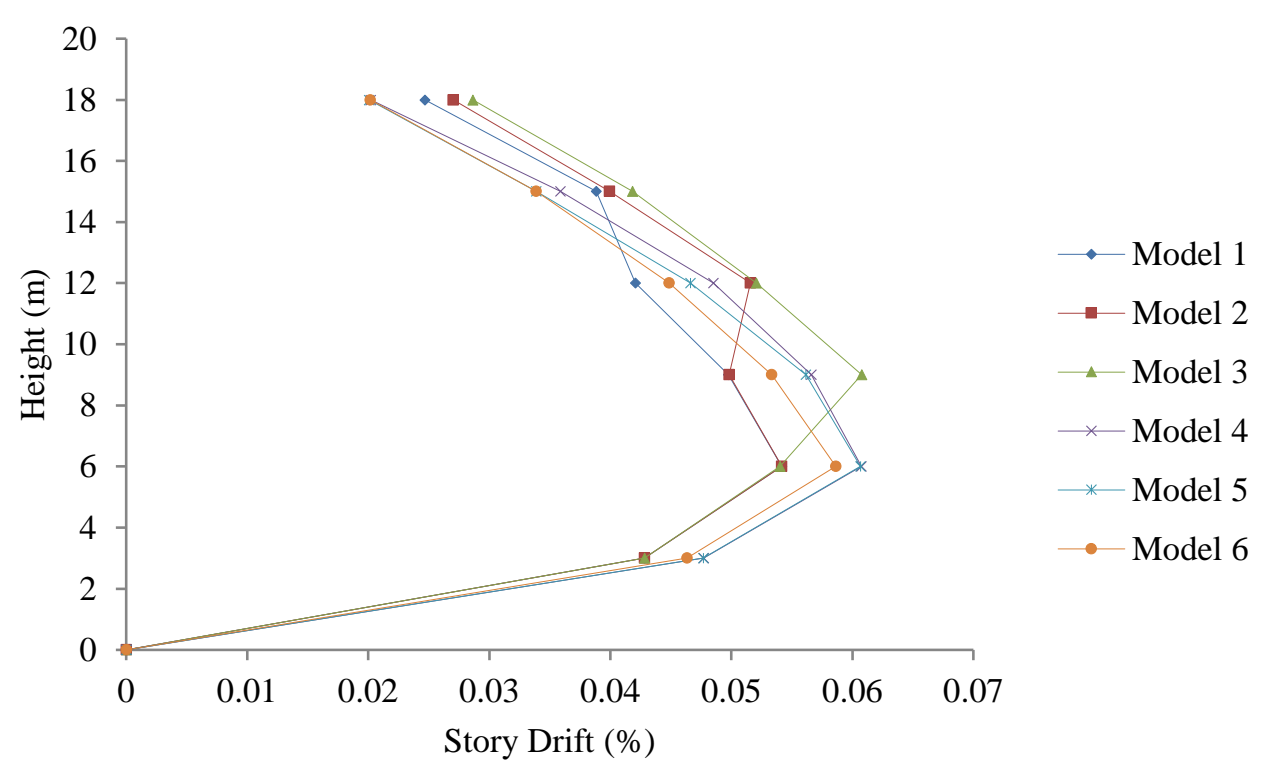

Fig. 4: Story Drift.

The location of peak story drift is same for the models with overhanging mass but not same for the models with mass discontinuity. It shifts with the change of the location of mass discontinuity. The formation of nonlinear hinges can be observed from Fig. 5. The location is same for all models and the first nonlinear hinge is generated in the beam of Level-1. But there is an important thing which should be discussed in this matter.

It is observed from Table 4 that formation of nonlinear hinge occurs at least base shear is in Model-4 while the value of base shear is highest in Model-1. There is a tendency of formation such hinges in less base shears in the models containing overhanging mass. This phenomenon depicts that the overhanging mass affects the nonlinear resistance of a frame. This effect is higher when the location of overhanging mass is in higher story levels.

Fig. 6 depicts the capacity curve of all models. The maximum value is for the Model-1 while the minimum stands for Model-4. It is substantial from the chart that discontinuity in lower story and overhanging mass in higher story delineate less value of base shear in capacity curve.

Fig. 7 and Fig. 8 illustrate the performance points of the models as per ATC-40. Fig. 7 shows the relationship between $S_{a}-S_{d}$. It can be observed that Model-1 can sustain at the earthquake with maximum acceleration while Model-4 is with the minimum acceleration among these models. From the following figure, it is obtained that the maximum $\mathrm{V} / \mathrm{W}$ value is for Model-1 while the minimum is for Model-4.

Table 5 depicts that the maximum value of ductility is for Model- 3 and the minimum value stands for Model-6. The ductility was determined using FEMA440 [12]. 


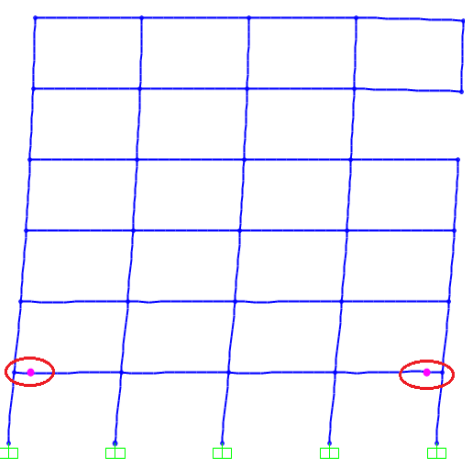

Model-1

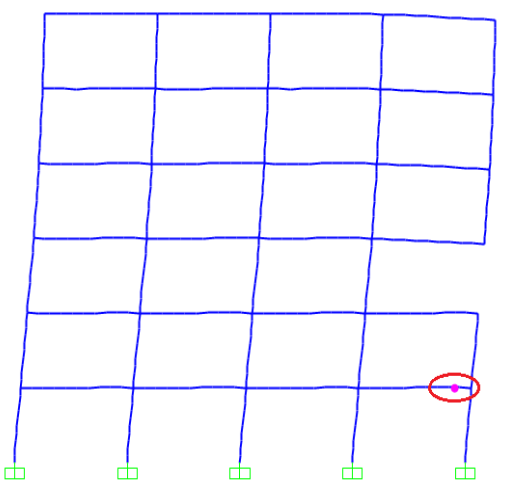

Model-3

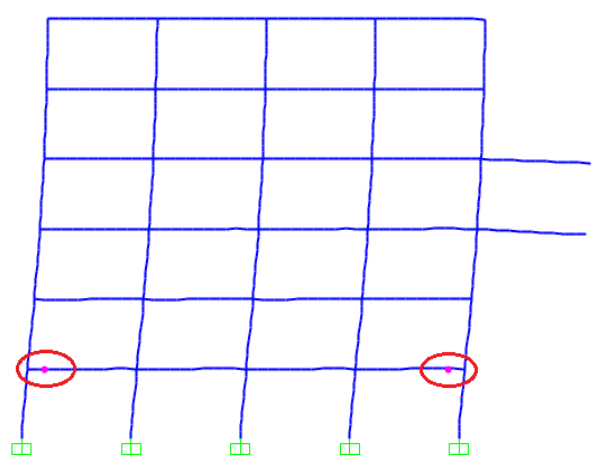

Model-5

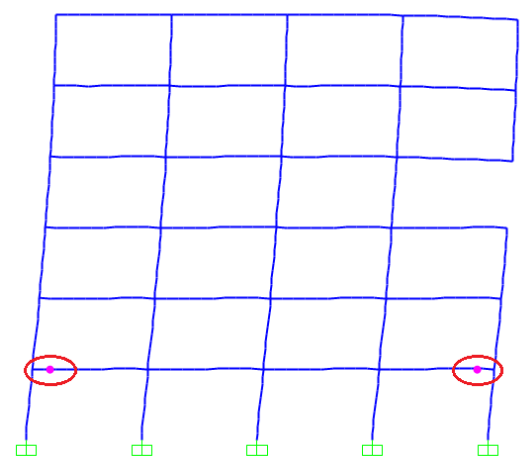

Model-2

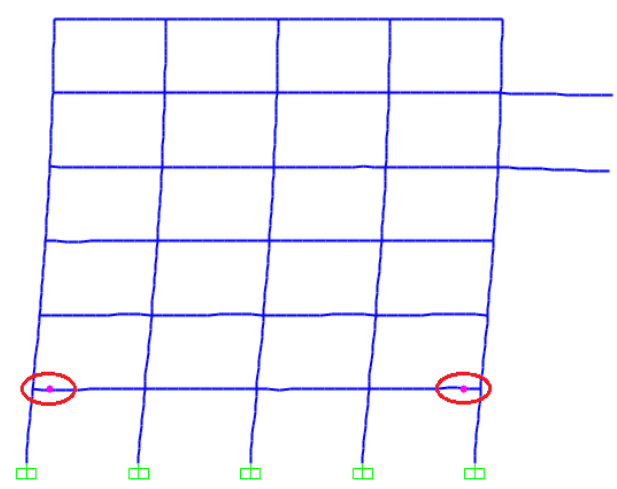

Model-4

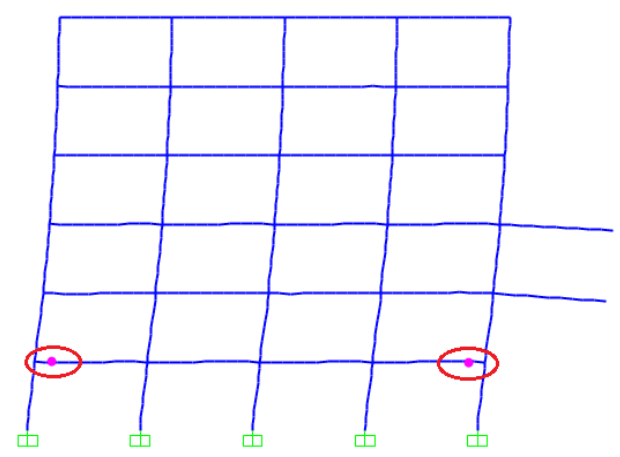

Model-6

Fig. 5: Formation of hinges in beams for different models.

Table 4 Nonlinear hinge formation.

\begin{tabular}{|l|c|c|c|}
\hline Models & IO $(\mathrm{W})$ & LS $(\mathrm{W})$ & CP $(\mathrm{W})$ \\
\hline Model 1 & 0.122491 & 0.134992 & 0.140245 \\
\hline Model 2 & 0.12132 & 0.133516 & 0.138596 \\
\hline Model 3 & 0.12028 & 0.12871 & 0.132497 \\
\hline Model 4 & 0.108504 & 0.118185 & 0.123462 \\
\hline Model 5 & 0.109203 & 0.120828 & 0.127135 \\
\hline Model 6 & 0.110118 & 0.121678 & 0.126049 \\
\hline
\end{tabular}




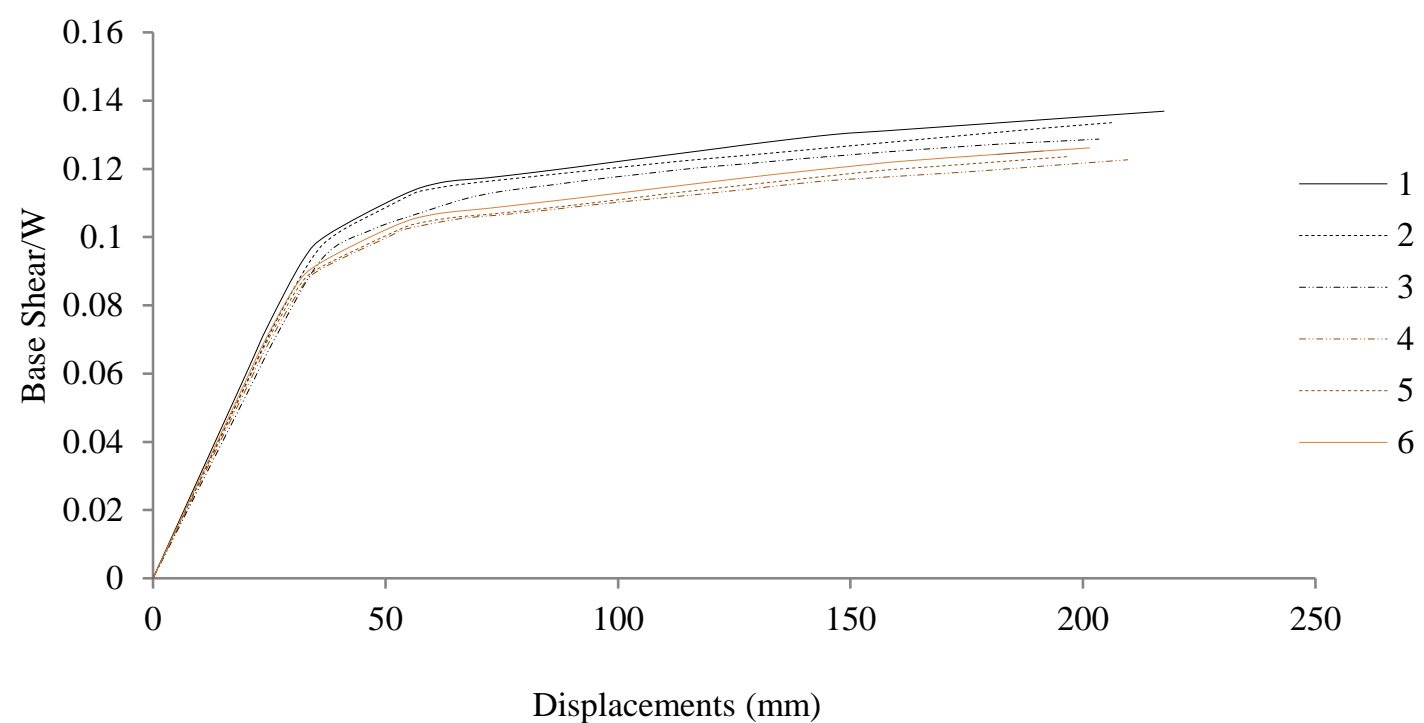

Fig. 6: Capacity curve of all specimens.
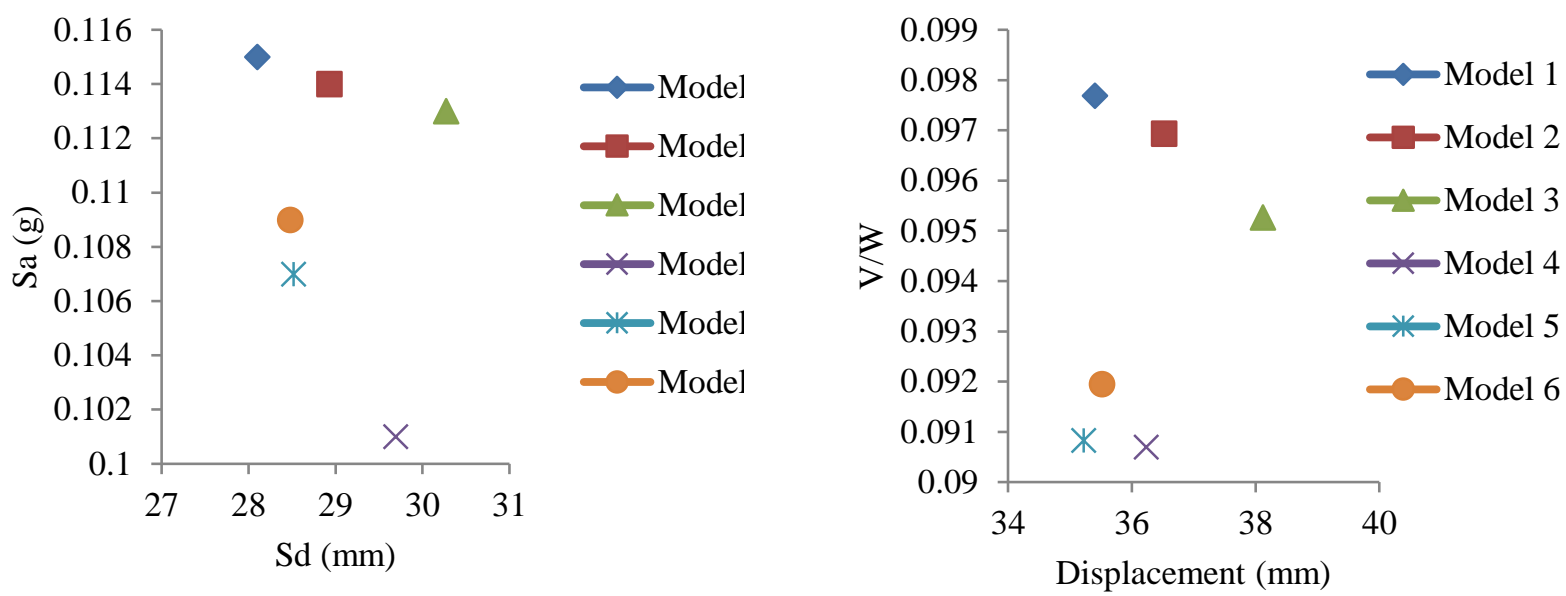

Fig. 7: Performance point $\left(\mathrm{S}_{\mathrm{a}}-\mathrm{S}_{\mathrm{d}}\right)$ as per ATC40.

Fig. 8 Performance point (V/W-D) as per ATC40.

Table 5: Ductility in different models.

\begin{tabular}{|c|c|}
\hline Models & Ductility \\
\hline Model 1 & 1.33 \\
\hline Model 2 & 1.332 \\
\hline Model 3 & 1.395 \\
\hline Model 4 & 1.36 \\
\hline Model 5 & 1.34 \\
\hline Model 6 & 1.325 \\
\hline
\end{tabular}

\section{Conclusion}

The numerical investigation mainly indicates that the story drift and lateral displacements has dependency based on the pattern of vertical geometric irregularity. From the numerical evaluation, a number of conclusions can be obtained as below: 
1. Vulnerability increases if the mass discontinuity locates at the lower story and overhanging mass in the higher story.

2. Mass discontinuity has effects on the peak story drift of a frame. The story drift suddenly increases where discontinuity of mass exists.

3. Overhanging mass doesn't affect the peak story drift locations.

4. Overhanging mass in higher story decreases the performance point to a good extent.

From the above discussion, it is evident that determining the position of overhanging mass and mass discontinuity should be descent to ensure better performance and stiffness of multistory building frames.

\section{References}

[1] Major Earthquakes in Bangladesh (2016). The Daily Observer.

http://www.observerbd.com/2016/01/05/129456.php. Accessed 5 January 2016.

[2] M. D. Stefano and B. Pintucchi, A review of research on seismic behaviour of irregular building structures since 2002. Bull Earthquake Eng 6 (2008) 285-308. doi.org/10.1007/s10518-007-9052-3.

[3] R. Tremblay and L. Poncet, Seismic Performance of Concentrically Braced Steel Frames in Multistory Buildings with Mass Irregularity, J. Struct. Eng. 131 (2005) 1363-1375. doi.org/10.1061/(ASCE)07339445(2005)131:9(1363).

[4] A. Aziminejad and A.S. Moghadam, Performance of asymmetric multistory shear buildings with different strength distributions, J. Applied Sci. 9 (2009) 1082-1089. http://dx.doi.org/10.3923/jas.2009.1082.1089.

[5] G. Georgoussisa, A. Tsompanosa and T. Makarios, Approximate seismic analysis of multi-story buildings with mass and stiffness irregularities, Procedia Engineering 125 (2015) 959 - 966. doi.org/10.1016/j.proeng.2015.11.147.

[6] C. Chintanapakdee and A.K. Chopra, Seismic response of vertically irregular frames: response history and modal pushover analyses, J. Struct. Eng.130 (2004) 1177-1185. doi.org/10.1061/(ASCE)07339445(2004)130:8(1177).

[7] N. Kara N and Z. Celep, Nonlinear seismic response of structural systems having vertical irregularities due to discontinuities in columns. Proceedings of Fifteen World Conference of Earthquake Engineering (2012). http://www.iitk.ac.in/nicee/wcee/article/WCEE2012_2685.pdf .

[8] E.V. Valmundsson and J. M. Nau, Seismic response of building frames with vertical structural irregularities, J. Struct. Eng. 123 (1997) 30-41.

https://ascelibrary.org/doi/abs/10.1061/\%28ASCE\%290733-9445\%281997\%29123\%3A1\%2830\%29

[9] Uniform Building Code 1997.

[10] FEMA 356, Prestandard and commentary for the seismic rehabilitation of buildings (2000).

[11] ATC40, Seismic evaluation and retrofit of concrete buildings Vol. 1 (1996).

[12] FEMA440, Improvement of nonlinear static seismic analysis procedures, 2005.

[13] A. Prabhu T., Seismic evaluation of 4-story reinforced concrete structure by non-linear static pushover analysis, National Institute Of Technology Rourkela, 2013.

[14] S.H. Hosseini, S.A. Bakar, K. Bagherinejad and E. Hosseinpour, Pushover analysis of reinforced concrete building with vertical shear link steel braces, Malaysian Journal of Civil Engineering 27 (2015) 169-179 http://civil.utm.my/mjce/files/2015/08/Vol-27-No-2-Paper-1.pdf

[15] Bangladesh National Building Code, 2006 